This is an Open Access article, distributed under the terms of the Creative Commons Attribution-

NonCommercial-ShareAlike licence (http://creativecommons.org/licenses/by-nc-sa/4.0/), which permits noncommercial re-use, distribution, and reproduction in any medium, provided the same Creative Commons licence is included and the original work is properly cited. The written permission of Cambridge University Press must be obtained for commercial re-use.

\title{
The Responsibility of European Archaeologists
}

\section{Cătălin Nicolae Popa}

Faculty of Archaeology, University of Leiden, The Netherlands

\begin{abstract}
In this article I address the relationship between European archaeologists and the European Union and argue that the dominant attitude of non-involvement that archaeologists have embraced over the past decades cannot be justified given recent political developments. The European project finds itself in a state of deep crisis, under siege from populist and far-right leaders within and around Europe. We cannot afford to watch from the sidelines when the future of hundreds of millions of people is at stake. As archaeologists we can make a positive contribution by harnessing the political dimension of our work, which we need to stop seeing in a negative light. We should deploy the past to help tackle the challenges of our society. European archaeologists should particularly focus on developing grand narratives of a shared past in Europe, to act as a foundation for a European identity.
\end{abstract}

Keywords: Europe, archaeology, politics, reflexive impotence, shared past, grand narratives

\section{INTRODUCTION}

The project of a united Europe ${ }^{1}$ is at a crossroads. For the past few years, the future of the European Union has looked increasingly precarious and the prospect of a political formation that will keep this otherwise bitterly divided continent at peace is slowly fading. Brexit, the refugee crisis, economic difficulties, and the increasing political gains of the far-right are all obstacles that slowly but surely erode the foundations of the European project. To top it all, there is a deep European identity crisis strangling the future of the continent (Andre, 2015).”

What should archaeologists do in this context? If we are to follow the advice of some authors (Babić et al., 2017: 5-7),

1 For ease of reading, I am using the terms European Union, Europe, the European project, and the European continent interchangeably. nothing at all. We should continue our comfortable slumber of non-involvement while the European project dissolves around us. As a European citizen, I cannot accept such a stance.

Here, I join the ranks of other scholars (González-Ruibal et al., 2018) to argue that archaeologists should openly engage with the challenges of our society and fully deploy the resources offered by our discipline. In particular, I call on European archaeologists to work towards building a shared European past. While this may not save the European Union, it would at least make it easier to establish a Europe-wide sense of identity.

\section{The Rise of the European Project}

The European Union is the fruit of the death and destruction that consumed the 
European continent for many centuries. Particularly, following the tragedy of the Second World War, the elites of Europe slowly built up an organization that could guard against horrors of which this continent has seen too much (Dinan, 2014: 23-52). The necessity of such an endeavour was already voiced by the likes of Winston Churchill, who in 1946 asked for a United States of Europe under which the European Family could dwell in peace (Churchill, 1946). Today we are closer than ever to such an edifice.

The European project was gradually put together throughout the second half of the twentieth century. Starting as a Steel and Coal Union, the project slowly grew into the European Economic Area, following several cornerstone meetings and treaties such as the Treaty of Rome (1957). After the Treaty of Maastricht (1992), the political organisation that we call today the European Union came into being, followed shortly by the European Monetary Union and the Schengen agreement on border controls (1995).

While the European Union was steadily taking shape in the west, much of central and eastern Europe was under the heavy iron fist of the USSR. Countries such as Hungary, Poland, or Bulgaria were forced to accept totalitarian communist regimes. This division between east and west, referred to as the Iron Curtain, would stand until 1989. Following Gorbachev's Perestroika, the USSR relaxed its hold on eastern Europe, which led to the fall of the Berlin Wall and gave the peoples of central and eastern Europe the freedom to find their own way. Most took this opportunity rapidly, embracing democracy, though the demons of the communist period, and the nationalist ideologies that accompanied them, came back at times to haunt these countries. Sometimes, such as during the disintegration of Yugoslavia, this took extreme forms, reminding everyone of the horrors that Europe was trying to leave behind.

The fall of communist regimes saw the continuous expansion of the European project towards the East. One by one, the Czech Republic, Romania, Croatia and others joined the European Union, giving further hope to the idea of a united Europe. As the last barriers across the continent are lifted the future of the European project should look bright and secure. But it does not.

\section{The Foundering Union}

Today's Europe may be closer than ever to Churchill's dream of a United States of Europe, but recent years have revealed deep cracks in the European edifice, running to its very core. The prospects of ever-looming economic austerity, the refugee crisis, the Greek bailout, and Brexit provide fuel for far-right parties that are winning more and more ground in numerous countries with their antiBrussels discourse. With every national parliamentary election in countries such as Germany, Italy, Hungary, or Poland, the European project is rapidly being chipped away $^{2}$.

The recent international political developments are also raising alarm bells as to the fate of the European Union. To the east, we witness the escalating anti-west rhetoric of Russian President Vladimir Putin and his aggressive external policy, culminating in the annexation of Crimea in 2014 (Snyder, 2018). To the west, the traditional ally of Europe, the USA, elected a president in 2016 that actively

2 I refer to the gains or wins made by parties such as Alternative für Deutschland (Germany), Movimento 5 Stelle and the Lega party (Italy), Sverigedemokraterna (Sweden), Fidesz and Jobbik (Hungary), Prawo i Sprawiedliwość (Poland). In Hungary, Poland, and Italy these parties hold the majority in their national parliaments. 
promotes disinformation and policies that come into conflict with European interests and values (Bennett \& Livingston, 2018). Once a candidate to join the European Union and strategic neighbour, Turkey has seen a serious turn towards totalitarianism, with the increasingly authoritarian regime of President Recep Tayyip Erdoğan (Çağaptay, 2017). Many other countries around the globe are embracing right-leaning governments. Populist leaders and populist politics in general are gaining ground both within and around Europe.

An intertwined and even more serious threat to the European Union comes from within and stems from a fundamental crisis of identity (Fukuyama, 2018: 140-53). People still identify themselves primarily through their national identities and events such as Brexit may even exacerbate this trend (Schlanger, 2017). There is a serious lack of attachment towards the European Union (Robyn, 2005; Karolewski et al., 2016). A recent survey by a Brussels-based think-tank found that nearly half of the over eleven thousand people surveyed thought that the European Union is irrelevant (Davies 2018; Friends of Europe, 2018). The need for a European identity has been signalled early on as a primary necessity for the success of the European project: the Declaration on European Identity, issued by the members of the European Community $^{3}$, dates to 1973. Efforts have been made to develop EU-wide symbols, such as an anthem and a flag, and to make citizens feel closer to the European institutions (Sonntag, 2011). However, most arguments for a European identity remained highly intellectual or theoretical, producing a message that mainly reached the educated echelons (Risse, 2004). What

3 See also the more recent reports by the European Commission, 2012, 2017. is ultimately needed to create a Europewide solidarity (sensu Habermas, 2015: 3-28) is an emotional attachment to the idea of Europe. Identity cannot be an intellectual exercise; it has to be felt. People need to start feeling European, feeling as a community of faith (sensu Giddens, 2014). That is one of the main areas in which the European Union has failed and where, I argue, archaeology can, and should, make its primary contribution.

\section{The Response of European Archaeology}

The connection of archaeology to the European project prior to the Treaty of Maastricht was minimal. With the early exception of Childe (1957), few works engaged with the idea of Europe and a wider European past. Attempts were made to employ the Roman Empire, the Bronze Age or the Celtic past as a precursor of the European edifice, but these usually transcribed in forgettable exhibitions and volumes that had little impact (e.g. Moscati et al., 1991).

After the 1990s and particularly during the 2000s there was not much improvement. If anything, the gap between archaeology and the European project increased even more. This may have occurred because a series of volumes brought the relationship between archaeology and nationalism in the past to attention (Kohl \& Fawcett, 1995; Díaz-Andreu \& Champion, 1996; GravesBrown et al., 1996). This added to an increasing acknowledgement that all our work was political in one way or another (Trigger, 1984; Kristiansen, 1993; Rowlands, 1994). The general reaction was for researchers to distance themselves even further from the political events that surrounded them. The increasing presence of the European Union as a funding body seems not to have helped either. While 
many project proposals excelled in using words that emphasized their European dimension (Niklasson, 2017) ${ }^{4}$, ultimately such expressions constituted windowdressing meant to increase the chances of securing funds. There are few volumes that truly have a European scope (e.g. Cunliffe, 2008). A notable exception is found in the work of Kristian Kristiansen, who has urged archaeologists to return to grand narratives (Kristiansen, 2008) and produced some publications that have a strong European component (e.g. Kristiansen et al., 2017).

The recent crises of the European project have occasionally stirred up reactions from archaeologists (e.g. Hamilakis, 2016), but overall have still left the discipline largely disconnected from political events. The destabilizing events affecting European society ${ }^{5}$ mainly resulted in the rise in popularity of conferences and projects that used buzzwords such as (economic) crisis or migration, but whose outcome did little to aid the struggles of Europe. It is only with the Brexit discussion, in which heritage issues have featured extensively (Bonacchi et al., 2018), that we have started seeing some European archaeologists responding (e.g. Gardner, 2017; Brophy, 2018; GonzálezRuibal et al., 2018; Hingley, 2018), along with scholars from other disciplines (e.g. Delanty, 2018).

The current dominant standpoint of archaeologists with regards to Europe can be found in the first pages of a recent article by Babic et al. $(2017)^{6}$ and can be

4 Some examples of projects are The Cradles of European Culture (http://www.cradlesec.eu), The Emergence of European Communities or Forging Identities: The Mobility of Culture in Bronze Age Europe (https://cordis.europa.eu/project/rcn/89457_en. html, Suchowska-Ducke et al., 2015).

5 I use the term European society following Delanty (2018: 143-57) as a relational field emerging from the interconnection of the different centres across Europe.

6 I take this collection of contributions as broadly expressing the main view of European archaeologists summarized in two words: stay out. While some of its contributors express more nuanced positions, Robb and Babić explicitly discourage interaction in the opening section of the article by stating that 'to try to build an emotive commitment to European identity [using archaeology] is a bad idea' (Babic et al., 2017: 6). The two authors argue instead for 'an organizational, not emotive, normality for "European archaeology" (Babic et al., 2017: 7). In practice this entails a complete separation from the developments taking place in Europe and goes against the realization of European officials that an emotive commitment to the European Union is imperative for its survival (Tusk, 2018). The message of Robb and Babic constitutes a significant step back when compared to the opinions expressed at the end of the 1990s (Pluciennik, 1998; Willems, 1999). It is asking of us to be archaeologists that work for institutions which coincidentally happen to be in Europe.

I contend that we are (European) citizens first and archaeologists second. We have a duty towards the people of today far more than to those from the past or the material culture they left behind ${ }^{7}$. We should therefore harness the power of the past to engage it as a resource for dealing with the challenges of today's European society and build a shared European past.

I argue for a shared rather than a common European past. The concept of shared past is analogous to the idea of shared culture briefly introduced by Delanty (2018: 213), which refers to shared reference points, without having an identical system of values attached to

given its numerous authors, and its title (What is 'European Archaeology'? What should it be?), and its publication as the first article in the first issue of the European Journal of Archaeology of 2017.

7 Nevertheless, giving a voice to the dead is definitely important (Bernbeck \& Pollock, 2018: 516). 
them. A large group of people can share a city, a territory, or even a practice, without having to relate to it in a similar manner. Delanty envisions in this manner a shared European culture which could promote solidarity while maintaining diversity.

A shared past would create a common platform without suppressing variety. Like a shared culture, a shared past refers to overarching narratives of the past to which different groups of people relate in a diversity of ways. A shared past implies grand narratives but leaves space for local contextualisation and interpretation, similarly to Ricoeur's (1995, 5-9) narratives of identity. For Europe, this refers to events or stories that were experienced by, or had an impact on, large parts of the continent. The ways in which various people from the different areas relate to an event do not have to be similar. The two World Wars or the Peace of Westphalia (1648) are examples of a shared past, as they affected the whole of Europe, though certainly not in the same manner. While less constraining than a common narrative, a shared European past can be the stepping stone towards a European sense of identity.

\section{Politics Is Not a DirTy Word}

To engage with the European project, we need to change our attitude towards the political dimension of archaeological research. In archaeology, saying that our work is political generally has a negative connotation. It somehow means that our work is impure, and even that it is not 'proper science'. It relates to how research results are employed to prop up a particular political ideology or, even worse, to how archaeological research is skewed to support some political agenda. Hence, we are told to take heed of the possible political implications of the research we produce (Ó Ríagáin \& Popa, 2012).
The examples chosen to illustrate the political dimension of archaeology often reinforce this perspective. Generally, nationalist and extreme-right regimes make for good case studies, though communist 'contaminated' archaeology is also sometimes cited. I have done so myself in several publications (e.g. Popa \& Ó Ríagáin, 2012; Popa, 2013; 2015). One can hardly go through a paragraph on the political dimension of archaeology without encountering references to Nazi Germany (Arnold, 1990) and the work of Gustaf Kossinna. Examples from the Balkans are also preferred, with Albania (Gori, 2012), Macedonia (Brown, 1994), or Romania (Niculescu, 2002) serving as examples of nationalistic archaeology, together with Spain during Franco's regime (DíazAndreu, 1993). All these works in themselves are necessary and even essential to understanding the negative direction that the political character of archaeology can lead to. But that is not all that this political dimension can bring.

Many political projects have had a positive dimension for society at large, or at least for some large groups of people. Although the deeply destructive nature of Nazi ideology is irrefutable, one can hardly say the same about Czech or Danish nation-building ${ }^{8}$.

The past is necessary for constructing national identity. While many, including myself, decried the close connection between archaeology and nationalism, we also refer to Hobsbawn's (1992: 3) famous quote that 'nations without a past are contradictions in terms'. One cannot create a sense of national identity without invoking the past. It is an essential part of establishing the solidarities than many embrace

8 Nevertheless, some episodes that had negative effects on one group or another can often be found in many cases of nation-building. In addition, one cannot overlook the tensions that such ideologies often brought between competing nations. 
and even hold dear. There is nothing inherently shameful in archaeology having participated in establishing the national narratives that helped build a sense of national belonging. On the contrary, many would find it a noble endeavour.

Deploying the political dimension of archaeology will not make our discipline any less scholarly. Archaeology lost its innocence a long time ago (Clarke, 1973). As people, we have always been caught up in the context of our time. As a discipline, our research was always to some degree or another intertwined with the political ideology of the time (Trigger, 1984). The only innocence was the one that we tried to argue for in our minds when we announced the 'scientific' and objective nature of our results. It is high time not only to leave that illusion behind, but also to accept the nature of the knowledge we produce and the impact that it can have in society. And, last but not least, to act on it.

The past's political dimension can be harnessed to bring about positive change in society. The past is already used as a powerful argument to empower marginalized groups (Funari \& Garraffoni, 2016) and to support indigenous rights movements (Colwell-Chanthaphonh et al., 2010; Prado Moi \& Fagundes Morales, 2011). In Europe, archaeology can help people come to terms with present-day developments that are difficult to digest. Narratives of the past can underline the long-standing multicultural and multiethnic character of the continent, making it easier to deal with the reality of the European Union. Hingley (2018) convincedly argues that some heritage sites, like the Roman frontiers, can function as an effective argument in this regard. The past can also ease the understandable anxieties that a considerable number of European citizens have experienced following the refugee crisis of 2015. By focusing on the commonalities between the past of
Europeans and the newly arrived refugees, it becomes easier to find a common ground between the two groups, helping to bridge the divide. This, in turn, helps justify societal decisions taken on moral rather than economic or functional arguments, such as chancellor Merkel's 2015 decision to open up Germany to refugees. Climate change, the eradication of poverty, or the circular economy, these are all topics for which the past can be a great advocate.

The past can be used to promote positive or negative, constructive or destructive, ideologies and behaviour. The choice between the arguments that history can potentially provide ultimately depends on the values and principles that individuals and groups decide to sustain (Bottici, 2008: 54). We should act so that the choice reflects our values and that of the communities we identify with, rather than allow political leaders of increasingly questionable ethical standards take that decision for us. I do not argue that archaeologists should act as the ultimate moral authority in society but I ask that archaeologists, rather than politicians, decide the values and agendas that our work supports. In the case of European archaeologists, I believe that we should act to strengthen the European edifice. We should leave the ivory tower of curiosity and education to a position of participation and involvement. Let us be constructive.

\section{The Danger of Fortress Europe9}

While archaeologists should participate in the construction of Europe, we must

9 Fortress Europe is an expression commonly used to refer to European isolationism. The term has been around since the planning and introduction of the European single market and monetary union (Huse \& Schwab, 1994). Recently, it has made a comeback following the refugee crisis of 2015 (Barbulescu, 2015; Zaragoza-Cristiani, 2017). 
remain highly vigilant not to fall into farright ideologies. We need to remember how archaeology was employed in some circumstances to justify or legitimate highly destructive measures and avoid those pitfalls. We also need to remain true to the archaeological record and use it to build overarching narratives without denying regional variability. And ultimately, while we may work towards building a common European identity, this must be open, acknowledging the fundamental influence of groups that came from beyond the continent.

Archaeology has helped legitimize monsters in the past and we can be sure that it can do so again. The dangers are real, and we must be aware of them but not let them paralyze us. The reason why the works on Nazi Germany mentioned earlier keep being brought up (Arnold, 1990; Härke, 2014) is because it is such an illustrative example of how archaeology can endorse a violent and destructive ideology. We should keep recalling how such a thing came to be, and refer to the numerous other cases, such as those from the Caucasus or the Balkans (Kohl, 1993; Harzl, 2011). We cannot afford to forget the warnings that are given by these examples and keep them in mind when engaging with the political dimension of archaeology.

We should be particularly wary of the uses the far-right may make of our work. Nationalist and far-right ideologies seem to have a fondness for the past. Our work often moulds easily to discourses that refer to the unique nature of a given group and contribute to arguments of exclusion. Because of this characteristic, right-wing or far-right governments may be more encouraging of archaeological research and can provide more funding for it. This can put archaeologists who do not agree with the political platform of those funding them in a quandary. But staying out of the political implications of our work is not the answer. On the contrary, trying to write a 'neutral' archaeology will simply create a past that lends itself to others' political agenda (Kristiansen, 1993: 3).

Writing a shared narrative of Europe does not mean falsifying the archaeological record. Our excavations have produced data that can serve to argue for a large array of stories. In writing our narratives we always put an emphasis on certain material traces and pick a particular reading of the material record over another based on our chosen perspective. However, this does not mean that anything goes. My argument is to give preference to Europe-wide narratives while staying true to the archaeological record. We should stand firm against outright false readings of material traces and combat any 'alternative facts', such as those generated by pseudo-archaeologists or fervent nationalists.

Producing a shared narrative of the European past does not mean eradicating regional differences. Some have expressed their concern that joining the European 'train' could lead to a hegemonic identity that suppresses regional variability (Babic et al., 2017: 6). There is no doubt that emphasizing shared European narratives would make national perspectives less dominant. However, thinking that they would completely supplant cultural variety is simply unrealistic. Regional traditions did not disappear in most countries despite the centralizing effort of nation states over several centuries. It is naïve to think that they would do so if European archaeologists prioritized continent-wide narratives. Furthermore, aiming for a shared, rather than common, past will leave ample space for a wide range of regional approaches and interpretations. Even so, I would prefer having research that can soften cultural differences for a peaceful society, rather than maintaining 
strong cultural differences with the risk of enhancing political or ethnic tension. We should build bridges not walls (Delanty, 2018: 211; Tusk, 2018).

We should not construct a narrative that excludes non-Europeans, but rather one that emphasizes European commonalities. There are understandable concerns that constructing a shared past for Europe will increase friction with people that do not see themselves as Europeans or may have moved to Europe from another part of the world. There is no denying that there cannot be an 'us' without a 'them', and hence to have Europeans there need to be non-Europeans. However, there are degrees to which one component is emphasized over the other. Archaeology can provide narratives that bring forward the commonalities of Europe and, at the same time, underline the strong cultural, demographic, and political influence of peoples from other areas, such as the Middle East, North Africa, and Asia. This can lead to a porous European identity, which would counteract moves towards Fortress Europe.

\section{Bullding a Shared Past of Migration}

The migration of peoples from the Yamnaya culture into Europe is a good example of a grand narrative that can function as a shared past. In a series of articles (Allentoft et al., 2015; Haak et al., 2015; Kristiansen et al., 2017), authors convincingly argued that the birth of the Corded Ware culture, and, through expansion, the European Bronze Age, can be attributed to a broad event taking place sometime around $3000 \mathrm{BC}$. This saw pastoralists from the Pontic-Caspian steppes migrate into Europe, where they came in contact with the Late Neolithic societies living there at the time. The new arrivals brought into Europe important new metalworking and animal husbandry technologies. Even more significantly, they brought a new language, Proto IndoEuropean, which fundamentally altered the linguistic landscape of the entire continent. The DNA of the newcomers left a strong imprint on the peoples of Europe, which can still be encountered today, from Norway to Sardinia (Haak et al., 2015: 210).

This story of migration works as a shared European past for several reasons. First, it is a process that affected a large part of Europe. Second, it left a lasting legacy on nearly the entire European continent technologically, culturally, linguistically, and genetically. And third, it is a narrative that lends itself to constructive ideas with regards to the multicultural character of Europe and the important role of peoples from beyond the continent in the emergence of Europeans and European culture.

A story of migration is particularly valuable given the refugee crisis that the European Union has been facing for the last few years. Such a narrative can help not only strengthen the social bonds of communities across the continent, but also contribute to allay the fears of some Europeans faced with a significant number of people arriving in Europe from Africa and the Middle East. By making this story well-known, by deliberately and insistently connecting it with the migrations taking place today across Europe, people may become more attuned and sensitive to the idea of migration as a constructive process. This can go as far as claiming that we were all migrants once and that all Europeans have a strong migrant heritage and migrant blood.

We should however not delude ourselves into thinking that this narrative is inherently positive. Its political message can easily be turned to emphasize the violence that such migrations can entail and 
the destabilizing effect it can have on society. This is a reading that the far-right would gladly sponsor and use. It is for this reason that archaeologists need to take ownership of the political message so as to deliver a constructive interpretation of the past and establish positive parallels to what is happening today.

Owning the political implications of our work requires us to grow a thick skin. Engaging with the burning and often divisive topics of our society, such as migration, will draw attention to our research and to us as individuals. This can result in a serious backlash, particularly in the social media. Some scholars like Mary Beard have experienced this first-hand. There is much to learn from her reaction ${ }^{10}$. Like her, rather than retreating in the face of such assaults, we should expose biases and continue promoting our work, political implications and all. At the same time, we should package our message in a manner that can reduce divisions rather than antagonize further the different elements of the public.

We should also be prepared for political pressure from governmental bodies. Research with overtly political implications will certainly come to the attention of politicians and government institutions. We can particularly expect reactions in countries where right-wing populist parties are highly influential. Given the volatile nature of academic positions and the dependency of much archaeological research on government grants, standing up to such pressure could prove painful. It is useful in such situations to openly discuss the impact of political constraints on our work, as well as the effects of our research on government policies (Niklasson \& Hølleland, 2018).

10 Mary Beard expressed her reaction in a series of blog posts, e.g. https://www.the-tls.co.uk/romanbritain-black-white/, https://www.the-tls.co.uk/policingtwitter-crowd-sourced-harrassment/.

\section{What European Archaeology SHOULD LOOK LIKE}

European archaeology should be an archaeology that makes a difference for the European continent as a whole. It should be a discipline that cares about the people of today and contemporary developments. It should address the challenges faced by our society and our contribution should be present in the public eye. And it should be an archaeology that produces panEuropean stories of the past.

Our research should aim at making a difference for the people of today by engaging with the challenges facing European society. The past is not an end of itself. Rather, it is a powerful resource that we as archaeologists can harness. European archaeologists should deploy this resource to help tackle the problems affecting the continent, from anxiety in the face of migration to sustainable economies and climate change. While some of these issues also have a broader, global dimension, they are all causes for which the past can provide a constructive narrative. A number of these topics have attracted the attention of archaeologists (e.g. Naudinot \& Kelly, 2017). This should be greatly increased, and the results and narratives produced should be far more prevalent in the public sphere.

Archaeology needs to make its presence felt. It is not enough to do research and write the report. Stories of the past must be transmitted and circulated widely among Europeans to have an impact. This involves actively targeting the public with our work and taking a public stance on the burning issues of today's Europe. We have complained too much about politicians using the past to create national narratives in the wrong ways. We should take ownership and engage directly with political projects rather than let the situation that we deplore simply continue. With 
such a change of stance, we should be prepared to deal with online backlash and pressure from political bodies.

Lastly, European archaeology needs to produce European stories. Archaeologists (Sherratt, 1995; Kristiansen, 2008) and historians alike (Guldi \& Armitage, 2014) have rightfully called for the return of grand narratives. Works that provide large, overarching stories of human societies are influential (e.g. Harari, 2014; Morris, 2017). Archaeologists should be knowledgeable at a European level and break the national confines that still limit our discipline (Kristiansen, 2008). We should be European archaeologists through our practice, not just through our label.

\section{Conclusion}

The European project is in danger of crumbling and the reaction of archaeologists has been all but lacking. Although today we are closer than ever to the Europe envisioned by Churchill, the multitude of crises affecting the European Union has shaken the project to its very core, making space for increased attacks from far-right movements and politicians. With few exceptions, European archaeologists have remained quiet, refusing to react to the developments around them, caught in a state of reflexive impotence (sensu Fisher, 2009: 21-30). In this article I plead for a change of attitude.

I argue that archaeologists should help Europe by accepting and acting upon the political dimensions of our discipline. Archaeological research often has strong political implications, which we should stop seeing in a negative light. We should accept responsibility for the political message of our work and deploy this resource to engage with the challenges of European society. However, we should guard ourselves from falling in the pitfalls of far-right exclusionary arguments and never forget the destructive ideologies that archaeology has been used to justify in the past.

Finally, I propose that European archaeology concerns itself with writing grand narratives about the roots of Europe. Our data may be about the past, but we write for the people of today. We should produce and actively employ narratives of the past to tackle the issues affecting Europe. We should focus in particular on writing a shared narrative that can act as a glue for a Europe-wide identity. While this alone may not rescue the European Union, it would at least make it easier for the peoples of Europe to see beyond their differences and encourage a sense of togetherness in a continent battered by centuries of war and hatred.

\section{ACKNOWLEDGEMENTS}

I would like to thank Dr. Maikel Kuijpers for having the patience to endlessly discuss the topic of the article with me over the last few years. I am also grateful for the feedback offered by Professor David Fontijn and Dr. Mariana De Campos Francozo. Lastly, I am thankful to Leiden University and The Nederlandse Organisatie voor Wetenschappelijk Onderzoek (NWO) for funding my research as part of the Economies of Destruction project under the VICI grant number 277-60-001.

\section{REFERENCES}

Allentoft, M.E., Sikora, M., Sjögren, K.-G., Rasmussen, S., Rasmussen, M., Stenderup, J., Damgaard, P.B., Willerslev, E., et al. 2015. Population Genomics of Bronze Age Eurasia. Nature, 522: 167-72.

Andre, V. 2015. Merah and Breivik: A Reflection of the European Identity Crisis. 
Islam and Christian-Muslim Relations, 26: 183-204.

Arnold, B. 1990. The Past as Propaganda: Totalitarian Archaeology in Nazi Germany. Antiquity, 64: 464-78.

Babić, S., Karl, R., Milosavljević, M., Mizoguchi, K., Paludan-Müller, C., Murray, T. et al. 2017. What is 'European Archaeology'? What should it be? European Journal of Archaeology, 20: 4-35.

Barbulescu, R. 2015. Inside Fortress Europe. Politique européenne, 47: 24-44.

Bennett, W.L. \& Livingston, S. 2018. The Disinformation Order: Disruptive Communication and the Decline of Democratic Institutions. European Journal of Communication, 33: 122-39.

Bernbeck, R. \& Pollock, S. 2018. Archaeology's 'People'. Antiquity, 92: 516-17.

Bonacchi, C., Altaweel, M. \& Krzyzanska, M. 2018. The Heritage of Brexit: Roles of the Past in the Construction of Political Identities through Social Media. Journal of Social Archaeology, 18: 174-92.

Bottici, C. 2008. Europe, War and Remembrance In: F. Cerutti \& S. Lucarelli, eds. The Search for a European Identity: Values, Policies and Legitimacy of the European Union. London: Routledge, pp. 45-58.

Brophy, K. 2018. The Brexit Hypothesis and Prehistory. Antiquity, 92: 1650-58.

Brown, K.S. 1994. Seeing Stars: Character and Identity in the Landscapes of Modern Macedonia. Antiquity, 68: 784-96.

Çağaptay, S. 2017. The Nerw Sultan: Erdogan and the Crisis of Modern Turkey. London \& New York: I.B. Tauris \& Co.

Childe, V.G. 1957. The Dawn of European Civilization (6th rev. ed.). London: Routledge \& Paul.

Churchill, W. 1946. Mr Winston Churchill speaking in Zurich I9th September 1946 [online] [accessed 21 November 2018]. London: The Churchill Society. Available at: <http://www.churchill-society-london. org.uk/astonish.html>

Clarke, D. 1973. Archaeology: The Loss of Innocence. Antiquity, 47: 6-18.

Colwell-Chanthaphonh, C., Ferguson, T.J., Lippert, D., McGuire, R.H., Nicholas, G.P., Watkins, J.E. \& Zimmerman, L.J. 2010. The Premise and Promise of Indigenous Archaeology. American Antiquity, 75: 228-38.
Cunliffe, B. 2008. Europe between the Oceans: Themes and Variations: 9000 bc-ad 1000. New Haven (CT): Yale University Press.

Davies 2018. EU is 'Irrelevant' According to Half of Europeans Surveyed [online] [accessed 20 October 2018]. Available at: $<$ https://www.euronews.com/2018/10/11/euis-irrelevant-according-to-half-of-thosesurveyed>

Delanty, G. 2018. The European Heritage: $A$ Critical Re-interpretation. London: Routledge.

Díaz-Andreu, M. 1993. Theory and Ideology in Archaeology: Spanish Archaeology under the Franco Regime. Antiquity, 67: 74-82.

Díaz-Andreu, M. \& Champion, T.C. eds. 1996. Nationalism and Archaeology in Europe. London: UCL Press.

Dinan, D. 2014. Europe Recast: A History of European Union. Second edition. Boulder (CO) \& London: Lynne Rienner.

European Commission, Directorate-General for Research and Innovation, Socio-economic Sciences and Humanities 2012. The Development of European Identity/Identities: Unfinished Business. A Policy Review. Brussels: European Commission.

European Commission 2017. Strengthening European identity through education and culture. The European Commission's contribution to the Leaders' meeting in Gothenburg, 17 November 2017. Strasbourg: European Commission.

Fisher, M. 2009. Capitalist Realism: Is There No Alternative? Winchester: Zero Book.

Friends of Europe 2018. \#EuropeMatters - A Message from Citizens [online] [accessed 20 October 2018]. Available at: <https:// www.friendsofeurope.org/publication/europematters-message-citizens>

Fukuyama, F. 2018. Identity: The Demand for Dignity and the Politics of Resentment. London: Profile Books.

Funari, P. \& Garraffoni, R. 2016. Participatory Archaeology and Community Empowerment in Brazil. Complutum, 27: 281-94.

Gardner, A. 2017. Brexit, Boundaries and Imperial Identities: A Comparative View. Journal of Social Archaeology, 17: 3-26.

Giddens, A. 2014. Turbulent and Mighty Continent: What Future for Europe? Cambridge: Polity Press.

González-Ruibal, A., González, P.A. \& CriadoBoado, F. 2018. Against Reactionary Populism: Towards a New Public Archaeology. Antiquity, 92: 507-15. 
Gori, M. 2012. Who Are the Illyrians? The Use and Abuse of Archaeology in the Construction of National and Transnational Identities in the Southwestern Balkans. Archaeological Review from Cambridge, 27: 71-84.

Graves-Brown, P., Jones, S. \& Gamble, C. eds. 1996. Cultural Identity and Archaeology: The Construction of European Communities. London: Routledge.

Guldi, J. \& Armitage, D. 2014. The History Manifesto. Cambridge: Cambridge University Press.

Haak, W., Lazaridis, I., Patterson, N., Rohland, N., Mallick, S., Llamas, B. et al. 2015. Massive Migration from the Steppe Was a Source for Indo-European Languages in Europe. Nature, 522: 20711. https://doi.org/10.1038/nature14317

Habermas, J. 2015. The Lure of Technocracy. Malden (MA): Polity.

Hamilakis, Y. 2016. Archaeologies of Forced and Undocumented Migration. Journal of Contemporary Archaeology, 3: 121-39.

Harari, Y.N. 2014. Sapiens: A Brief History of Humankind. London: Harvill Secker.

Härke, H. 2014. Archaeology and Nazism: A Warning from Prehistory. In: V. Mordvintseva, H. Härke \& T. Shevchenko, eds. Archaeological and Linguistic Research: Materials of the Humboldt-Conference. Kiev: Stilos, pp. 32-42.

Harzl, B.C. 2011. Nationalism and Politics of the Past: The Cases of Kosovo and Abkhazia. Review of Central and East European Law, 36: 53-77.

Hingley, R. 2018. Frontiers and Mobilities: The Frontiers of the Roman Empire and Europe. European Journal of Archaeology, 21: 78-95.

Hobsbawm, E.J. 1992. Ethnicity and Nationalism in Europe Today. Anthropology Today, 8: 3-8.

Huse, J.A. \& Schwab, B.J. 1994. Fortress Europe and the EC Single Market Initiatives. (International Construction). International Business Lawyer, 22: 155-64.

Karolewski, I.P., Kaina, V. \& Kühn, S. 2016. European Identity Research in Times of Crisis: Introduction. In: V. Kaina, I.P. Karolewski \& S. Kühn, eds. European Identity Revisited: New Approaches and Recent Empirical Evidence (Critical European Studies 4). London: Routledge, pp. 21-32.
Kohl, P.L. 1993. Nationalism, Politics, and the Practice of Archaeology in Soviet Transcaucasia. Journal of European Archaeology, 1: 181-89.

Kohl, P.L. \& Fawcett, C. eds. 1995. Nationalism, Politics, and the Practice of Archaeology. Cambridge: Cambridge University Press.

Kristiansen, K. 1993. 'The Strength of the Past and its Great Might'; An Essay on the Use of the Past. Journal of European Archaeology, 1: 3-32.

Kristiansen, K. 2008. Do We Need the 'Archaeology of Europe'? Archaeological Dialogues, 15: 5-25.

Kristiansen, K., Allentoft, M.E., Frei, K.M., Iversen, R., Johannsen, N.N., Kroonen, G. et al. 2017. Re-theorising Mobility and the Formation of Culture and Language among the Corded Ware Culture in Europe. Antiquity, 91: 334-47.

Morris, I. 2017. Foragers, Farmers, and Fossil Fuels: How Human Values Evolve. Princeton (NJ): Princeton University Press.

Moscati, S., Arslan, E. \& Vitali, D. eds. 1991. The Celts. New York: Rizzoli.

Naudinot, N. \& Kelly, R.L. 2017. Climate Change and Archaeology. Quaternary International, 428: 1-2.

Niculescu, G.A. 2002. Nationalism and the Representations of Society in Romanian Archaeology. In: I. Vainovski-Mihai, ed. Nation and National Ideology: Past, Present and Prospects. Bucharest: New Europe College.

Niklasson, E. 2017. The Janus-face of European Heritage: Revisiting the Rhetoric of Europe-making in EU Cultural Politics. Journal of Social Archaeology, 17: 138-62.

Niklasson, E. \& Hølleland, H. 2018. The Scandinavian Far-right and the New Politicisation of Heritage. Journal of Social Archaeology, 18: 121-48.

Ó Ríagáin, R. \& Popa, C.N. 2012. Introduction. Archaeological Review from Cambridge, 27: 1-9.

Pluciennik, M. 1998. Archaeology, Archaeologists and 'Europe'. Antiquity, 72: 816-24.

Popa, C.N. 2013. The Trowel as Chisel: Shaping Modern Romanian Identity through the Iron Age. In: V. Ginn, R. Enlander \& R. Crozier, eds. Exploring Prehistoric Identity: Our Construct or Theirs? Oxford: Oxbow, pp. 164-74. 
Popa, C.N. 2015. Late Iron Age Archaeology in Romania and the Politics of the Past. Dacia N.S., 59: 337-61.

Popa, C.N. \& Ó Ríagáin, R. 2012. Archaeology and Nationalism in Europe: Two Case Studies from the Northwest and Southeast of Europe. Archaeological Review from Cambridge, 27: 52-70.

Prado Moi, F. \& Fagundes Morales, W. 2011. Archaeology and Paresi Cultural Heritage. In: C. Gnecco \& P. Ayala Rocabado, eds. Indigenous Peoples and Archaeology in Latin America. Walnut Creek (CA): Left Coast Press, pp. 315-31.

Ricoeur, P. 1995. Reflections on a New Ethos for Europe. Philosophy \& Social Criticism, 21: 3-13.

Risse, T. 2004. European Institutions and Identity Change: What Have We Learned? In: R. Herrmann, T. Risse \& M. B. Brewer, eds. Transnational Identities: Becoming European in the EU. Lanham (MD): Rowman \& Littlefield, pp. 247-72.

Robyn, R. 2005. Introduction: National versus Supranational Identity in Europe. In: R. Robyn, ed. The Changing Face of European Identity: A Seven-Nation Study of (Supra) National Attachments. London: Routledge, pp. 1-16.

Rowlands, M. 1994. The Politics of Identity in Archaeology. In: G C. Bond \& A. Gilliam, eds. Social Construction of the Past. London \& New York: Routledge, pp. 129-43.

Schlanger, N. 2017. Brexit in Betwixt. Some European Conjectures on its Predictability and Implications. The Historic Environment: Policy \& Practice, 8: 212-22.

Sherratt, A. 1995. Reviving the Grand Narrative: Archaeology and Long-term Change: The Second David L. Clarke Memorial Lecture. Journal of European Archaeology, 3: 1-32.

Snyder, T. 2018. The Road to Unfreedom: Russia, Europe, America. New York: Tim Duggan Books.

Sonntag, A. 2011. False Expectations: The Counterproductive Side Effects of the EU's Use of Political Symbols. In: S. Lucarelli, F. Cerutti \& V.A. Schmidt, eds. Debating Political Identity and Legitimacy in the European Union. London: Routledge, pp. 115-30.
Suchowska-Ducke, P., Reiter, S.S. \& Vandkilde, H. eds. 2015. Forging Identities: The Mobility of Culture in Bronze Age Europe. Report from a Marie Curie Project 2009-2012 with Concluding Conference at Aarbus University, Moesgaard 2012 (BAR International Series 2771). Oxford: British Archaeological Reports.

Trigger, B.G. 1984. Alternative Archaeologies: Nationalist, Colonialist, Imperialist. Man, 19: 355-70.

Tusk, D. 2018. Ceremonial lecture by President Donald Tusk following the award of the Honorary Doctorate from the Technical University of Dortmund [online] [accessed 20 December 2018]. Brussels: Press office, General Secretariat of the Council. Available at: <https://www. consilium.europa.eu/en/press/press-releases/ 2018/12/16/ceremonial-lecture-by-presidentdonald-tusk-at-the-technical-university-ofdortmund/\#>

Willems, W.J.H. 1999. The Future of European Archaeology. Oxford: Oxbow Books.

Zaragoza-Cristiani, J. 2017. Containing the Refugee Crisis: How the EU Turned the Balkans and Turkey into an EU Borderland. The International Spectator, 52: 59-75.

\section{BiographicAl Notes}

Cătălin Popa is a postdoctoral researcher at the Faculty of Archaeology, Leiden University. He works on the relationship between archaeology and politics, particularly with regards to group identity construction. He also works with statistical modelling, specializing in introducing human perception in archaeological data and landscape analysis.

Address: Cătălin Popa, Faculty of Archaeology, Department of World Archaeology, University of Leiden, Einsteinweg 2, Leiden $2333 \mathrm{CC}$, The Netherlands. [email: pcatalinn@yahoo. com] 


\section{La responsabilité des archéologues européens}

Cet article traite des relations que les archéologues européens entretiennent avec l'Union Européenne et soutient que l'attitude dominante adoptée par ces archéologues au cours des dernières décennies, c'est-àdire de ne pas intervenir, ne peut être justifiée au vu des récents évènements politiques. Le projet européen est en proie à une profonde crise, menacé à l'intérieur et à l'extérieur du continent par des dirigeants populistes et d'extrême droite. Nous ne pouvons nous permettre de rester à l'écart quand l'avenir de centaines de millions de personnes est en train de se jouer. En tant qu'archéologues, nous pouvons avoir une influence positive en exploitant le caractère politique de notre travail, un aspect que nous devons cesser de voir sous un angle négatif. Il convient d’utiliser les ressources du passé pour faire face aux défis lancés à notre société. Les archéologues européens auraient intérêt à développer des " grands récits " traitant d'un passé européen partagé qui pourraient servir de fondation à une identité européenne. Translation by Madeleine Hummler

Mots-clés: Europe, archéologie, politique, impuissance de la réflexion, passé partagé, "grands récits »

\section{Die Verantwortung der europäischen Archäologen}

Dieser Artikel betrifft die Beziehungen zwischen den europäischen Archäologen und der Europäischen Union und es wird hier behauptet, dass die vorherrschende Einstellung der Archäologen in den letzten Jahrzehnten, eine Art Nichteinmischungspolitik, angesichts der jüngsten politischen Entwicklungen nicht mehr vertretbar ist. Das europäische Projekt befindet sich in einer tiefen Krise und ist von populistischen und rechtsextremen Leitern innerbalb und außerbalb der Europäischen Union bedroht. Wir können nicht einfach Zuschauer bleiben, wenn es um die Zukunft von Hunderten von Millionen von Menschen geht. Als Archäologen können wir einen positiven Einfluss haben, indem wir die politische Dimension unserer Arbeit nutzbar machen; dabei müssen wir uns abgerwöhnen, diese politische Dimension in einem negativen Licht zu sehen. Wir sollten die Vergangenheit einsetzen, um die Herausforderungen unserer Gesellschaft zu bewältigen. Die europäischen Archäologen sollten den Schwerpunkt auf "großen Erzäblungen" legen, die eine gemeinschaftliche europäische Vergangenheit darstellen und die als Grundlage für eine europäische Identität dienen können. Translation by Madeleine Hummler

Stichworte: Europa, Archäologie, Politik, Machtlosigkeit der Überlegung, gemeinschaftliche Vergangenheit, „große Erzählungen“ 